\title{
豫後並びに治療成績から觀た再生不良性貧血の考察
}

\author{
京都大學医學部蔽池內科(主任 菊池郄授) \\ 菊池武崖，說田武，鐮旧秀雄 \\ 占山他佔雄, 池田健治, 森本義男

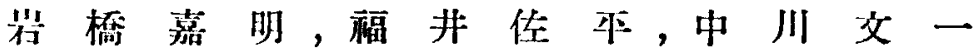

\section{OBSERVATIONS OF APLASTIC ANEMIA CONSIDERING FROM THE VIEWPOINT OF PROGNOSIS AND CURATIVE EFFECT.}

\section{By}

T. Kikuchi, T. Setsuda, H. Kamada, T. Yoshiyama,

K. Ikeda, Y. Morimoto, Y. Iwahashi,

S. Fukui, B. Nakagawa.

The 2nd Medical Clinic, Kyoto University Medical School

(Director: Prof. T. Kikuchi).

29 cases of aplastic anemia admitted to our clinic were observed mainly from the viewpoint of prognosis and curative effect and the following results were obtained:

Age, hemorrhagic diathesis, blood pictures and bone marrow pictures were believed to be likely a good indicator to determine prognosis: general speaking, bad prognosis was found relatively in high frequency either in older patients over 60 years or in younger ones under 20. Gingival bleeding and petechiae in the skin were observed in many cases, but bloody stool, genital bleeding, meningeal hemorrhage, large epistaxis and retinal bleeding were found only in cases with bad prognosis.

A prolongation of bleeding time or clotting time and a decreased blood capillary resistance were found in either cases. It was revealed that after treatment the prolongation of bleeding time was markedly reduced in many cases with good prognosis, but on the contrary, in cases with bad prognosis the prolongation of the time was found to be much increased. In blood pictures R.B.C. count under 1.5 millions per $\mathrm{cmm}$, blood platelet count under 30,000 per $\mathrm{cmm}$ or W.B.C. count under 3,000 per $\mathrm{cmm}$ was observed considerably in large number of cases. In the differential count decreased neutrophils under $40 \%$. increased lymphocytes over $50 \%$, decreased monocytes under $3 \%$ or aeosinophils was observed frequently in cases with bad prognosis, while not so frequently in those with good prognosis. It was difficult to determine prognosis by means of the nucleal cell count of sternal punctate.

The decrease of either nucleated red cell under $10 \%$ or granulocyte under $40 \%$ in the differential count of myelogram was found in many cases with bad prognosis. 
Repeated blood transfusion (inclusive of intrasternal transfusion) and therapeutics such as folic acid (especially in large dose), vitamin $B_{12}$ or methionine were considered to be effective and above all, the combination therapy of blood transfusion and folic acid was the most effective. Consequently it was believed that early diagnosis and early treatment are the most important and also that this disease needs especially improvement of blood disorders as well as treatment of hemorrhagic diathesis.

\section{I 緒 言}

再性不良性貧血（以下再不貧之略）の研究は從 來形態的方面から翮々行われ(1)-13)，又最近では

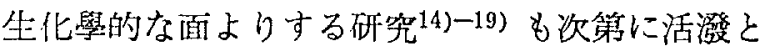
なり，かくして本疢患の本態究明に向つて大いな る络力が拂われつっある。一力又，本聅患の治療 についても種々研究されているが，今日问本聅患 の治療法は確立されていない，此處に於いて猭後 或は治療の面から，本疾患を檢討することは谌だ 有意義なことと考えられる。

さきに我々は本誌上に於いて再不賀の臨床像並 びに物䚀代謝に就いて報告15)したが，今包は更に 症例を追加して過去17年間に當内科に入院した再 不貧患者29例について，豫後並びに治療成績を中 心として種々檢討を行なつたので以下これについ て述へる。

\section{II 杼後を中心として觀た考察}

\section{1）症例の分類}

前記29例を沿療效果の面方方 A 群 ( 3 例), B群 （3例)，C群（10例）及びD群（13例）の4群に 分忛た。

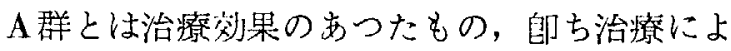
り殊に血液像が略く正常に復し，又骨脢造像に於い ても著しい改請めたもの，B群とは稍て治療 效果のあつたもの, 即ち治療により血液像が稍て 著明に回復し，文骨慥像に見られた障害も可成り 著明に輕減されたもの，C群と治浩效果の不確

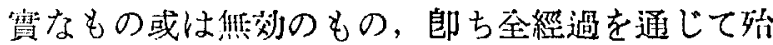
ぞ治療効果を認めなかつたもの或は極めて一過性 の治療効果を認めたもの或は又觀祭期間が短く， 從つて范分に治療効果を確め得なかつたもの，D

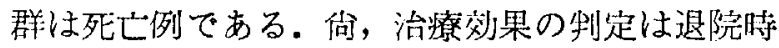

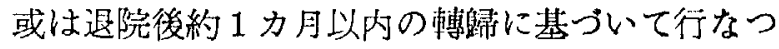

た．以下，上記29例について豫後を中心として次 の數項目に分けて考祭してみる。

2）年令, 性, 遺傳歷, 既徙歴, 職業及び住所： 第 1 表は上記29例を年令及び性別にわけたもので ある.郋ち，年令别では29例中 20 才以下 4 例， 21 ３0才10例，31 45才 5 例，46 60才5例，60才 以上 5 例である。 その内 $\mathrm{A}$ 及び B君では21 60才 が大多數を占め, 之に反しD群では20才以下及び 60 才以上のものが過半數を占める。，性別では

第 1 表 性及び年令

\begin{tabular}{|c|c|c|c|c|c|c|}
\hline & & A 群 & B 群 & C 群 & D群 & 計 \\
\hline \multirow{2}{*}{ 性 } & 特 & 3 & 1 & 7 & 7 & 18 \\
\hline & 女 & 0 & 2 & 3 & 6 & 11 \\
\hline \multirow{3}{*}{ 年 } & 20 才以下 & 0 & 1 & 0 & 3 & 4 \\
\hline & $20 \sim 30$ 打 & 1 & 0 & 7 & 2 & 10 \\
\hline & $30-45$ 才 & 1 & 1 & 0 & 3 & 5 \\
\hline \multirow{3}{*}{ 令 } & $45 \sim 60$ 才 & 1 & 1 & 2 & 1 & 5 \\
\hline & 60 才以上 & 0 & 0 & 1 & 4 & 5 \\
\hline & 備 考 & & -48 & $\begin{array}{r}1-7 \\
7\end{array}$ & $\begin{array}{r}16 \sim 60 \\
\text { 才 }\end{array}$ & \\
\hline
\end{tabular}

（注） A 群：治療效果を認めたもの

B 群：稍了治療効果のあつたもの

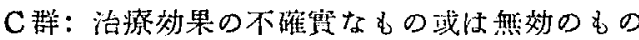
$\mathrm{D}$ 群：死亡例

策 2 表 遗傅歴

\begin{tabular}{|c|c|c|c|c|c|}
\hline & A群 & B 群 & $\mathrm{C}$ 群 & $\mathrm{D}$ 群 & 計 \\
\hline 結 核 & 1 & 1 & 4 & 4 & 10 \\
\hline 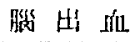 & 2 & 0 & 3 & 4 & 9 \\
\hline 㟨息 & 0 & 1 & 2 & 2 & 5 \\
\hline 㴼 & 0 & 0 & 1 & 3 & 4 \\
\hline 糖 疲 病 & 0 & 0 & 1 & 1 & 2 \\
\hline 私滩惨患 & 0 & 0 & 0 & 0 & 0 \\
\hline 粠神 病 & 1 & 0 & 0 & 0 & 1 \\
\hline 其 の他 & 1 & 0 & 0 & 0 & 1 \\
\hline
\end{tabular}


第 3 丧 既 往 歴

\begin{tabular}{|c|c|c|c|c|c|c|c|}
\hline & & & A 群 & B 群 & 群 & D 群 & 計 \\
\hline 梅 & & 婊 & 2 & 1 & $\cdot$ & 2 & 5 \\
\hline 結 & & 核 & 1 & & 2 & 1 & 4 \\
\hline \multirow{7}{*}{ 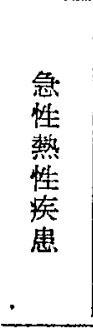 } & 肺 & 炎 & & & 2 & 2 & 4 \\
\hline & $\nabla \quad 7$ & 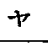 & 1 & & 1 & 1 & 3 \\
\hline & 淋 & 病 & 1 & & 1 & & 2 \\
\hline & ワ 1 ル 比 & 㾈 & 1 & & & & 1 \\
\hline & 腸 $千 7$ & $x$ & & & 1 & & 1 \\
\hline & $\begin{array}{llll}\text { チ } & \nearrow & \boldsymbol{\top} & \text { リ } \\
\end{array}$ & - & & & 1 & & 1 \\
\hline & 其 9 & 他 & 1(虫垂炎) & 1(急性腎㷋) & & 1 (疫痢) & 3 \\
\hline \multirow{2}{*}{ 寄生虫 } & 鈎 虫 & 症 & & 1 & 3 & 1 & 5 \\
\hline & 蜔 虫 & 拄鿊 & & & & 1 & 1 \\
\hline 慢 & 性 雷 腸 疾 & 患 & & & & 2 & 2 \\
\hline 肝 & 朠疾 & 患 & & & & (胆菙炎黄㾞) & 2 \\
\hline \multirow{6}{*}{ 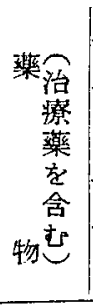 } & ガ ル バルサ & $\Sigma$ & 1 & 1 & & 2 & 4 \\
\hline & チフス・ワクチ & & 1 & & & & 1 \\
\hline & ストレブトマイシ & & & & & 1 & 1 \\
\hline & バ & $x$ & & & & 1 & 1 \\
\hline & キニーネ・アテプリ & & & & 1(兩者) & & 1 \\
\hline & 其 & 他 & & 1 & $2\left(\begin{array}{l}\text { ヒロポン } \\
\text { ガンツン }\end{array}\right)$ & 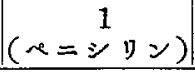 & 4 \\
\hline
\end{tabular}

第 4 表 躍 病 日 数

\begin{tabular}{|c|c|c|c|c|c|c|}
\hline & & A 群 & 群 & 群 & 群 & 計 \\
\hline \multirow{6}{*}{$\begin{array}{l}\text { 發迄 } \\
\text { 病の } \\
\text { 後日 } \\
\text { 入數 } \\
\text { 院 }\end{array}$} & 1 力月以丙 & 0 & 0 & 0 & 1 & 1 \\
\hline & 1 一力月 & 0 & 1 & 1 & 1 & 3 \\
\hline & 3 一 6 力月 & 2 & 0 & 0 & 8 & 10 \\
\hline & 6 力月 1 年 & 1 & 2 & 4 & 3 & 10 \\
\hline & 1 年以上 & 0 & 0 & 5 & 0 & 5 \\
\hline & 䚚 考 & 5 力月一 1 力年 & 3 力月一 2 力年 & 3 力月一 6 力年 & 1 力月一 9 力月 & 1 力月一 6 力年 \\
\hline \multirow{6}{*}{$\begin{array}{l}\text { 入 } \\
\text { 院 } \\
\text { 日 } \\
\text { 數 }\end{array}$} & 1 力月以丙 & 0 & 0 & 2 & 7 & 9 \\
\hline & $1 \sim 3$ カ月 & 0 & 0 & 2 & 3 & 5 \\
\hline & $3 \sim 6$ 力月 & 1 & 1 & 0 & 2 & 4 \\
\hline & 6 力月一 1 年 & 0 & 1 & 5 & 0 & 6 \\
\hline & 1 年以上 & 2 & 1 & 1 & 1 & 5 \\
\hline & 備 考 & 6 力月一-3年5力月 & 7 力月 -3 年 4 力月 & 1年3力月〜 7日 & $16 力$ 月 $\sim 3$ 日 & 3 年 5 力 2 - 3 日 \\
\hline \multirow{4}{*}{$\begin{array}{l}\text { 治 } \\
\text { 療 }\end{array}$} & 3 力月以丙 & & 1 & 3 & 7 & 11 \\
\hline & $3 \sim 6$ 力月 & 1 & & & 4 & 5 \\
\hline & 6 力月〜 1 年 & & 1 & 3 & 1 & 5 \\
\hline & 1 年 2 年 & & & 2 & 1 & 3 \\
\hline 日 & 2 年〜 3 年 & 1 & & 1 & & 2 \\
\hline \multirow[t]{2}{*}{ 數 } & 3 年以上 & 1 & 1 & 1 & & 3 \\
\hline & 考 & 5 カ月ー3.年10カ月 & 3 カ月 -3 年 10 カ月 & 7日－3年 6 力月 & 3日～1年 4 力月 & 3日一-3年 6 力月 \\
\hline
\end{tabular}


妝18例，女11例で，A群では3例とも男子である が，D群では13例の内約半數が女子であつた。遗 傅歴では結核, 㛴出血, 喘息, 癌が比較的多いが

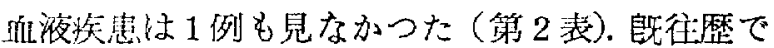
は梅毒，結核及び急性熱性疾患（特に肺炎，マラ リア）が比輺的多い. 㕛墢病前に使用した藥物と してはサルバルサンが多くここれによつて發病し たと思われる2例は何れもA及びB群に留し，良 好な經過を辿つた. (第 3 表). 職業別では本症上 特に關係があると思われるものはなかつたが，医 師，看護掃，寫貪業及びガソリンを取扱う工員が各 1 例見られた。住所别では都會生活者が18例で， 殘りの11例は田舎に住居を有するものであつた。

3）檌病日數：筂病後入院迄の經過日數はA， B茂びD群に於いては大望がないが，C群では1 年以上のものが約半數に於いて認められ，而も加 っることは他の群では見られなかつた，又破病よ 的退院迄の日數はA 群では 2 年以上のものが 3 例 中 2 例，之に反しD群では總へて 2 年以内で，殊 に 年以内のものが大多数（13例中11例）であ
る。治療日數は入院の有無に拘らず，A及び B群 では 6 カ月以上のものが多く，之に反しD群では 大多數のものが 6 力月以内でする. 又群では 7 日乃至 3 年 6 力月に没び，各症例により長短種タ である(第 4 表).

4）入院前の治療の有無：入院前に沿療を受け たものと受けなかつたものとの比率はA及びB群 第 5 表 出血性素兵

\begin{tabular}{|c|c|c|c|c|c|}
\hline & A 群 & B 群 & C群 & D 群 & 計 \\
\hline 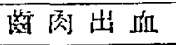 & 1 & 2 & 9 & 6 & 18 \\
\hline 皮下出淔 & 1 & 1 & 8 & 6 & 16 \\
\hline 血 & & & 4 & 9 & 13 \\
\hline 下 血 & & & 3 & 2 & 5 \\
\hline 眼底出血 & & & 1 & 2 & 3 \\
\hline 庤 出 血 & & & & 2 & 2 \\
\hline 腦脱出血 & & & & 1 & 1 \\
\hline 腿結膜出血 & & & & 1 & 1 \\
\hline 血 展 & & & 1 & & 1 \\
\hline 珄器出䘏 & & & & 1 & 1 \\
\hline 例 & 3 & 3 & 10 & $\cdot 13$ & 29 \\
\hline
\end{tabular}

第 6 表 出血時間及び擬固時間（治療の前，後）

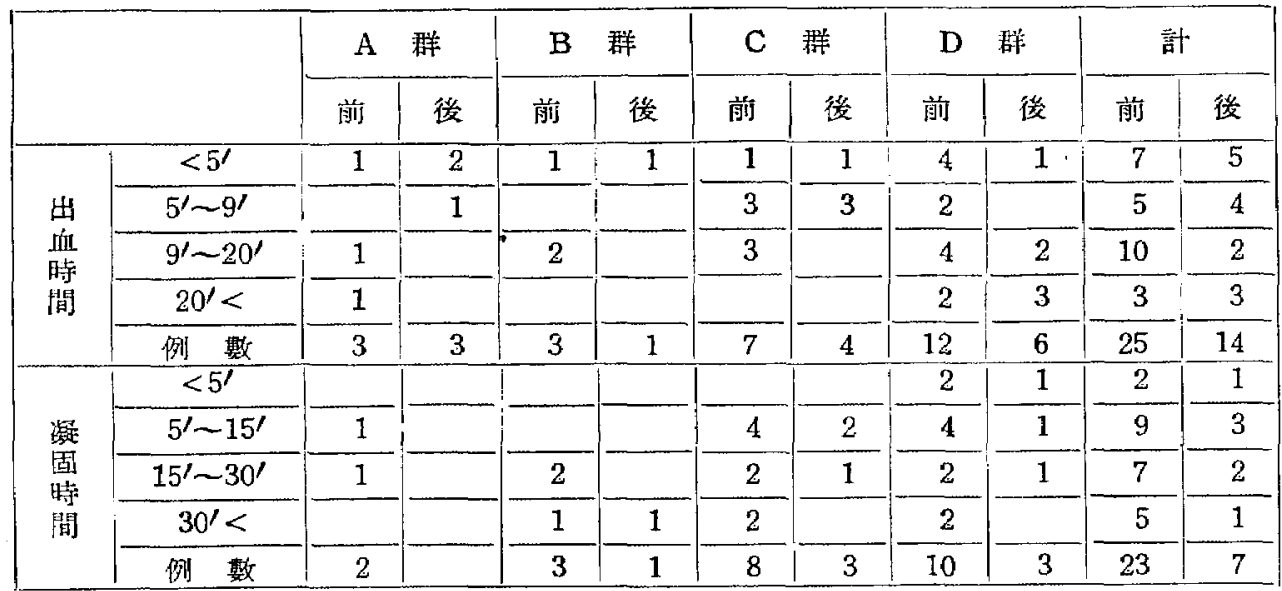

第 7 表 肝臟機能檢督（治療の前，後）

\begin{tabular}{|c|c|c|c|c|c|c|c|c|c|c|c|}
\hline & \multicolumn{2}{|c|}{ A 群 } & \multicolumn{2}{|c|}{ B 群 } & \multicolumn{2}{|c|}{ C 群 } & \multicolumn{2}{|c|}{ D 群 } & \multicolumn{2}{|c|}{ 計 } \\
\hline & & 前 & 後 & 前 & 後 & 前 & 後 & 前 & 復 & 前 & 後 \\
\hline \multirow{5}{*}{$\begin{array}{l}\text { 肝腀機 } \\
\text { 能障害 }\end{array}$} & $(-)$ & 1 & & 1 & 1 & 4 & 2 & 2 & 2 & 8 & 5 \\
\hline & $(+)$ & & & 1 & & 1 & 1 & 2 & & 4 & 1 \\
\hline & (H) & & & & 1 & & & & 1 & & 2 \\
\hline & (H) & & & & & & & & & & \\
\hline & 例数 & 1 & 0 & 2 & 2 & 5 & 3 & 4 & 3 & 12 & 8 \\
\hline
\end{tabular}


第 8 表 治療前後の末梢血使像

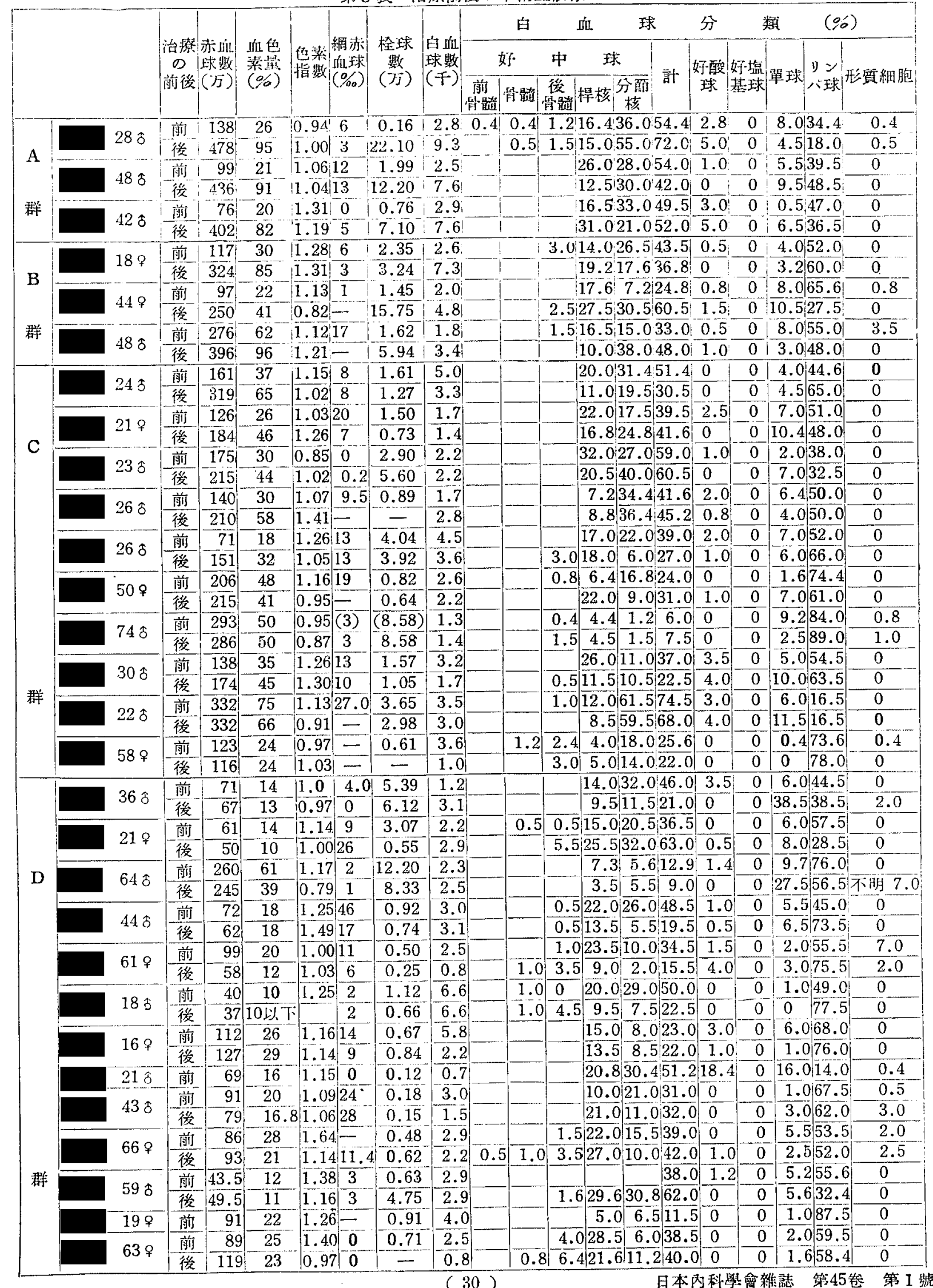


第 9 表末梢血液像（その I)（治療の前後）

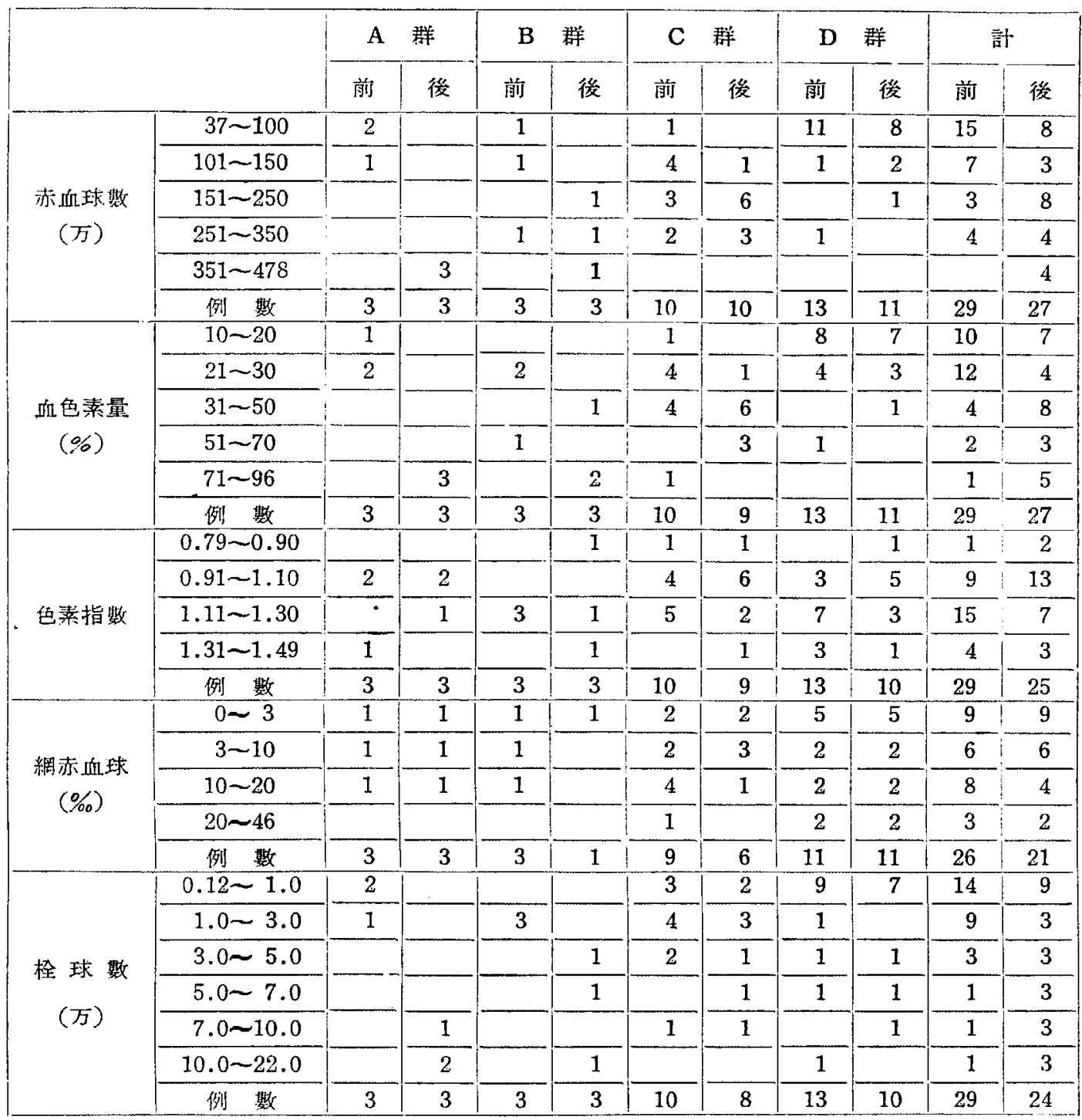

では4：2，又C及びD群では 9：14である。郎 ち治療を受けたものは此較的A 及びB群に多く， 之に反しC及びD群に少ない。

5）入院時の自，他覺症狀：入院時の自覺症狀

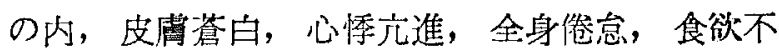
振, めまい, 呼吸困難, 耳鳴, 熱感等の主として 貧血に基づく症狀が各群共に高獄に見られた。 又 入院時の他學症狀の内, 輕度の榮荃障害, 發熱, 出血性素質, 赤沈の速進, 獨樂音, 畈腫脹等方各 群共に高率に認められた。然し脾腫は㒖か 2 例に 於いて輕度のものが認められたのみで, 又D群で
は比較的榮荃不良のものが多い傾问を認めた。出 血性素質の内で齒肉出血, 皮下出血注各群共に多 數認められたが, 鼻血, 不血, 性器出血, 眼底出 血等はC及びD群に於いてのみ認められた（第 $\mathbf{5}$ 表).出血時間の延長は各群共に殆どその全例に見 られた。しかして治療後 $\mathrm{A}$ 及びB群では出血時間 が正常に復する傾问を認めたが，これに反し D群 では治療にも拘らず，調查したものの内では増惡 の傾向を示すものが多く見られた。命，血液凝固 時間の歪長せるもの，Rumpel-Leede 氏現象陽性 のもの，或は毛細血管抵抗の減弱を示すものは各 
第10表 末梢㚗液像（その 2)（治療の前，後）

\begin{tabular}{|c|c|c|c|c|c|c|c|c|c|c|c|c|}
\hline & & & \multicolumn{2}{|c|}{ A 群 } & \multicolumn{2}{|c|}{ B 群 } & \multicolumn{2}{|c|}{ C 群 } & \multicolumn{2}{|c|}{ D 群 } & \multicolumn{2}{|c|}{ 計 } \\
\hline & & & 前 & 後 & 前 & 後 & 前 & 後 & 前 & 後 & 前 & 後 \\
\hline \multirow{5}{*}{\multicolumn{2}{|c|}{ 白 向球 數 }} & $760 \sim 3,000$ & 3 & & 3 & & 5 & 8 & 10 & 8 & 21 & 16 \\
\hline & & $3,000-5,000$ & & & & 2 & 5 & 2 & 1 & 2 & 6 & 6 \\
\hline & & $5,000 \sim 6,000$ & & & & & & & 1 & & 1 & \\
\hline & & $6,000 \sim 9,300$ & & 3 & & 1 & & & 1 & 1 & 1 & 5 \\
\hline & & 例 數 & 3 & 3 & 3 & 3 & 10 & 10 & 13 & 11 & 29 & 27 \\
\hline \multirow{6}{*}{ 白 } & \multirow{5}{*}{$\begin{array}{c}\text { 好中球 } \\
(\%)\end{array}$} & $6 \sim 20$ & & & & & 1 & 1 & 2 & 3 & 3 & 4 \\
\hline & & $20 \sim 40$ & & & 2 & 1 & 5 & 5 & 7 & 5 & 14 & 11 \\
\hline & & $40 \sim 50$ & 1 & 1 & 1 & 1 & 1 & 2 & 3 & 1 & 6 & 5 \\
\hline & & $50-74.5$ & 2 & 2 & & 1 & 3 & 2 & 1 & 2 & 6 & 7 \\
\hline & & 例 政 & 3 & 3 & 3 & 3 & 10 & 10 & 13 & 11 & 29 & 27 \\
\hline & \multirow{5}{*}{$\begin{array}{l}\text { リンバ } \\
\text { 球(\%) }\end{array}$} & $14 \sim 30$ & & 1 & & 1 & 1 & 1 & 1 & 1 & 2 & 4 \\
\hline \multirow[t]{4}{*}{ 血 } & & $30 \sim 50$ & 3 & 2 & & 1 & 3 & 3 & 3 & 2 & 9 & 8 \\
\hline & & $50 \sim 70$ & & & 3 & 1 & 3 & 4 & 7 & 4 & 13 & 9 \\
\hline & & $70 \sim 89$ & & & & & 3 & 2 & 2 & 4 & 5 & 6 \\
\hline & & 例 數 & 3 & 3 & 3 & 3 & 10 & 10 & 13 & 11 & 29 & 27 \\
\hline \multirow{4}{*}{ 百 } & \multirow{6}{*}{$\begin{array}{c}\text { 單 球 } \\
(\%)\end{array}$} & $0 \sim 3$ & 1 & & & 1 & 3 & 2 & 5 & 6 & 9 & 9 \\
\hline & & $3 \sim 5$ & & 1 & 1 & 1 & 2 & 2 & & & 3 & 4 \\
\hline & & $5-10$ & 2 & 2 & 2 & 1 & 5 & 4 & 7 & 3 & 16 & 10 \\
\hline & & $10-20$ & & & & & & 2 & 1 & & 1 & 2 \\
\hline \multirow{2}{*}{ 分 } & & $20 \sim 38.5$ & & & & & & & & 2 & & 2 \\
\hline & & 例 数 & 3 & 3 & 3 & 3 & 10 & 10 & 13 & 11 & 29 & 27 \\
\hline \multirow{6}{*}{ 㻭 } & \multirow{6}{*}{$\begin{array}{c}\text { 好酸球 } \\
(\%)\end{array}$} & 0 & & 1 & & 1 & 4 & 5 & 6 & 6 & 10 & 13 \\
\hline & & $0 \sim 3$ & 3 & & 3 & 2 & 5 & 3 & 5 & 4 & 16 & 9 \\
\hline & & $3-5$ & & 2 & & & 1 & 2 & 1 & 1 & 2 & 5 \\
\hline & & $5-10$ & & & & & & & & & & \\
\hline & & $10 \sim 18.4$ & & & & & & & 1 & & 1 & \\
\hline & & 例 數 & 3 & 3 & 3 & 3 & 10 & 10 & 13 & 11 & 29 & 27 \\
\hline
\end{tabular}

群共に認められたが, 各群相瓦の比較或は治滰前 後の比較は例數がそしく，困難である(第 6 表). 向又䀒機能檢查を行なつた結果では，正常のもの が多く, 機能障害は12例中僅かに 4 例で, 而も輕 度のものであつた (第 7 表).

6）血液像（第8,9,10表）：第 8 表は全症例の 治療前後に於ける末梢血液である。赤血球數の高 度の減少（150万以下）はA，B，Dの各群では 殆ど全例に，又C群では約半數に見られた。它し て治療後A群では全例が 400万至 480万迄に, 又 B群では 3 例中 2 例が 300 万至 400 万迄に回復し たが，C群では約半數に於いて多少回復の傾向を 認めたのみで，D群では全く回復の徵を見なかっ
た，血色素量の著減(30\%以下)は赤血球數のそれ と同じく, C群では約半數に, 其他の群では殆ど 全例にみられた。治療後血色素量はA 群では全例 共80乃至 $95 \%$ に, 又B群では 3 例中 2 例が70乃至 96\%に迄回復したが，D群では殆ど大多數のもの に於して治療後むしろ減少の傾向がみられた. 又, C群では治療後粎半數のものが多少回復の傾向を 示したに過きない，網赤血球數では各群共に減少 （3\%以下）のみならず，反對に増加(10\%以上) するものが見られた。而して減少を示すものは B兩群に比較的少なく，之に反し增加を示すもの は C，D群に比較的多く見られた。殊にD群で は増加と減少が相半ばするが，最高46\%に達した 
ものが 1 例みられた。栓球數の高度減少（ 3 万以 下) は $\mathrm{A}, \mathrm{B}$ 兩群の全例, $\mathrm{C} 及 ひ ゙ \mathrm{D}$ 群の大多數の ものに芫られた。治療後栓球數はA群では全例共 7 万全22万（2例は10万以上）に, 叉B群では 3 乃至15万（2例は 6 万以上）に夫々回復したが， $\mathrm{C}$ 群では 8 例中 5 例が 5 万以下に, 又D群では10 例中 8 例が 1 万以下に止まつた（第 9 表). 白血球 數の高度の減少 ( 3,000 以下) はA，B兩群の全 例, D群の大多數のもの及びC群の約半數のもの にみられた。治療後白血球數はA群では全例とも 略 $て$ 正常值 (6,000 以上) に㞔り，B群でもこれ に比し多少程度は輕いが回復が見られた。しかる にC及びD群では治療後も白血球數が3,000 以下 に止まるのが大多數を占めた，好中球百分率の著 減（40\%以下）を示すものはA群にはないが， B 群では 3 例中 2 例にみられ, 又 $\mathrm{C}, \mathrm{D}$ 兩群で!主半 數以上に虫められた。沿療後これが増加する傾向 はA，B兩群では著明にみられたが，C群では約 半數にみられたのみで，D群では治ど全く認めら れなかつた、リンパ球百分率の増加（50\%以上） はA群には見られず，C，D兩群では過半數のも のに, 又内群では全例に見られた。治療後，A及 びB群ではリンパ球百分率の減少する傾问を認め たが，C，D兩群では治療による變化は殆ど認め られなかつた。好酸球の消失或は简球比率の減少 (3\%以下) は何れもA，B兩群にはみられない か或は濑めて少數にみられるのみであるが，之に 反し C，D兩群（殊にD群）では比較的多くのも のに見られた。しかも治療後これ等には一定の變 化を認め得なかつた（第10表）。

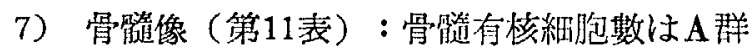
では 17,000 58,000, B群では4,900 270, 000 , C 群では 11,000 130,000, D群では7, 700 〜 170,000 である. 郎ち， A群でも著滅するも のがあり，反對にC或はD群に於いて比輘的高值 を示すものがある，從つて骨䢥有核細胞數と各群 との關係は詳かでない。然しながら治療後 A， B 兩群では大多數のものに於いて有核細胞數が增加 するか或は正常に㙫する傾向が見られたが，C，D
网群では變化がないか或はむしろ減少の傾向が認 められた。台，出血死を來たしたD群の1例では， 死亡前の有核細胞數は入院時と較へて大差がな く，13万と云う正常值を示した．赤牙球比率は $\mathrm{A}$ 或はB群では17.0 98.0\%で，その内著明な増加 （60\%以上)を示すものが約半數にみられ，又D群 では 2.3〜 70.6\%で，その内10\%以下の著減を示 すものは僅か 2 例で, 多くのものが略と正常值を 示し，1例ではむしろ著增（70.6\%）を認めた。 C群では13.8〜 126.0\%で, その内60\%以上のも のは 2 例あるが，10\%以下の減少を示すものはな い. 治療後赤芽球比率は $\mathrm{A} ， \mathrm{~B}$ 兩群では何れも正 常に復するか,或は増加の傾向を示すが， C群では 不變のものが過些數を占め, 又D群ではむしろ減 少の傾向を示すものが過半數に於いてみられた。 好中球比率が $40 \%$ 以下に著減するものはB，C兩 群では各 1 例に見られたのみであるが，D群では その約半數のものに於いて見られた，而して治療 後 A，B兩群では治療前にこれが低值を示したも のでは増加の傾向を示すが，之に反し C，D兩群 では著變がなく，死亡した1例では 5.5\%(治療前 注42.0\%）に著減した。好塩基球及び好酸球比率 は各群相互の間に著しい盖がなく，又治療による 一定の傾向も見られない．單球比率もこれ等と略 々相似な關係にあるが，ただD群の2例に於いて 著明なる增加（50\%以上）を認めた。本2 例の内 1 例注肝膿瘍, 又他の 1 例は, 肺アスペルギール ス感染を伴なつた例である、リンパ球比率の増加 （30\%以上）は各群に見られた。その內 $45 \%$ 以上 の著増はD群の的半數のものに見られたが，他の 3 群では極めて少數で, 殊に60\%以上の増加はD 群の 2 例のみに認められた。份，各群共に成熟障 害が赤牙球或は好中球の何れかに或は丈この兩者 に於いて程度の差はあるが認められる．而して治 療後はA，B兩群ではこれら細胞の成熟障害が正 常化する傾向が認められたがこれに反し C，D

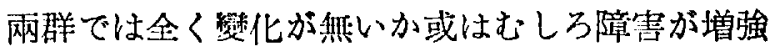
するものが多く見られた。

8）血清及び尿中の催筫血性物質：患者12例に 


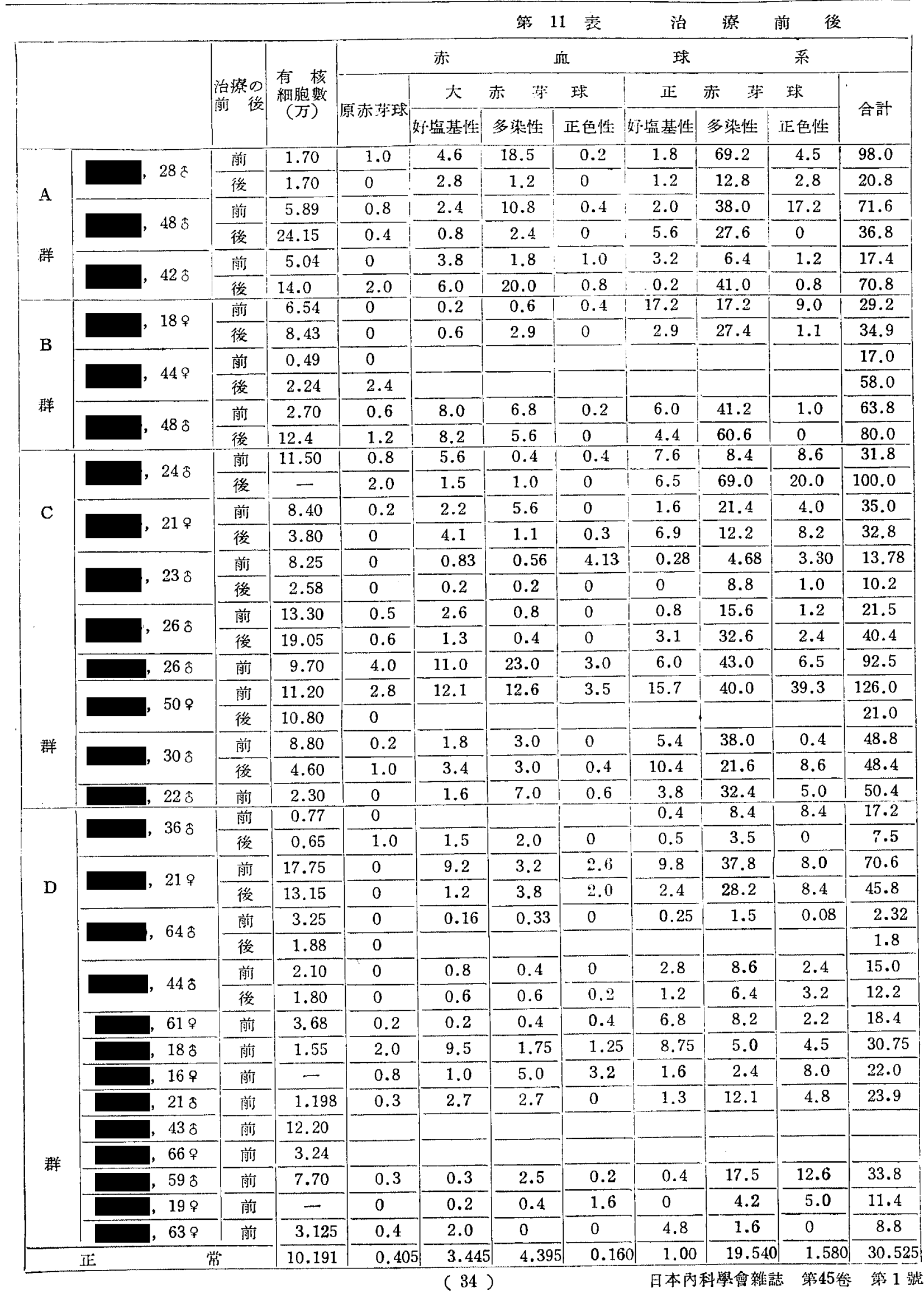




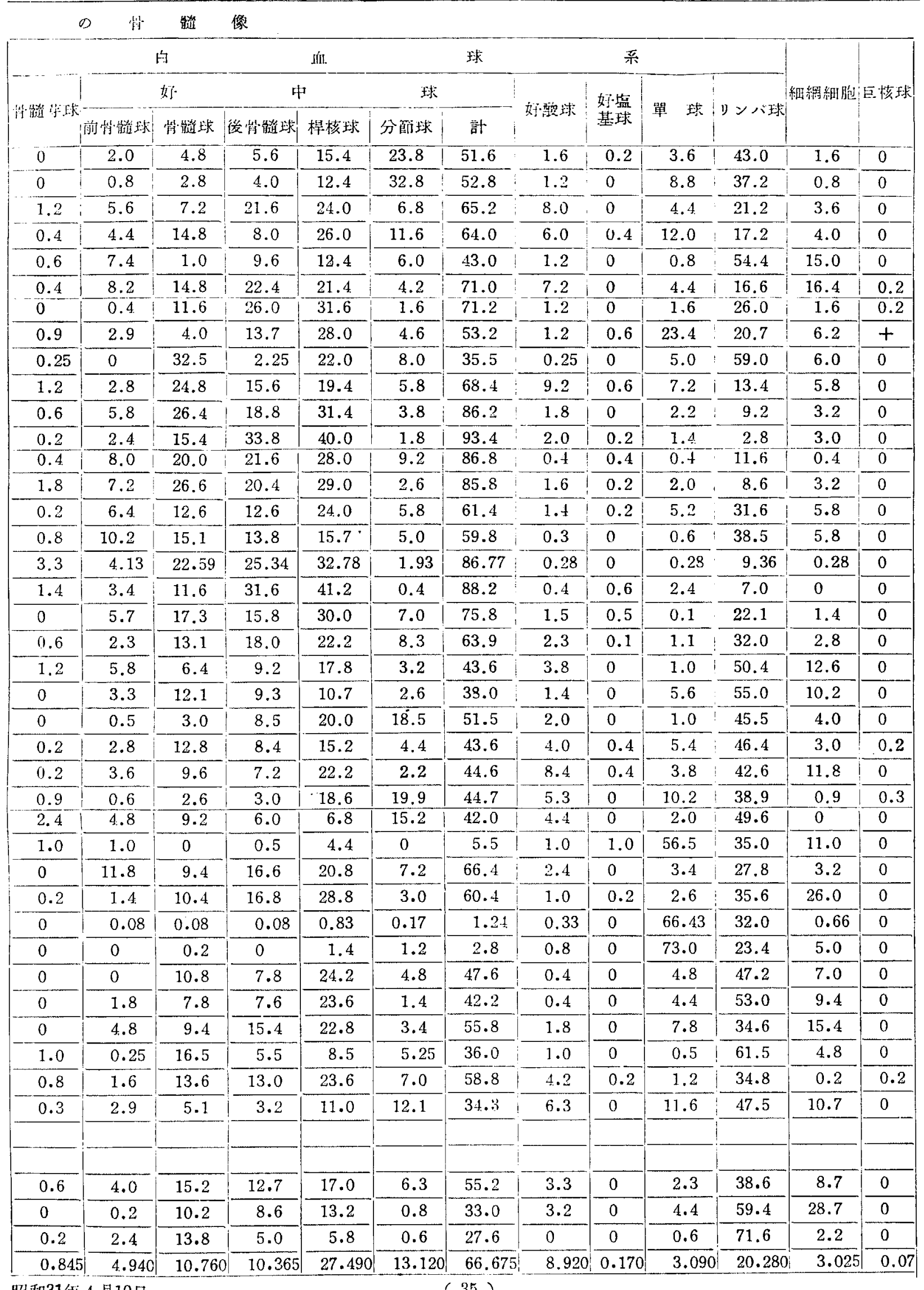


ついて血清及び尿中の所謂，催貧血性物翼の出現 頻度を調べた(第12表). 本物質を証明するには家 曱页はラッテに患者の血清或は濃縮尿を夫々静注 或は皮下注射(夫々1回或は連續10司)して，赤血 球數, 血色素量及び柽球數の最大減少率を求め, これを健康人の對照值と比較するのであるが，こ れについては既に我々の報告したところである。 前記12例の患者では血清及び尿中に催貧血性物翼 の存在を全例に於いて証明し得たが，たぐA及び B群の内には, 他の群に比へて血清或は尿の催貧 血作用が多少弱いものが見られた。

第12表 再不贫患者の血清及び濃縮永注射家兔に 於ける赤血球數最大減少率(催筫血性物犋の証明)

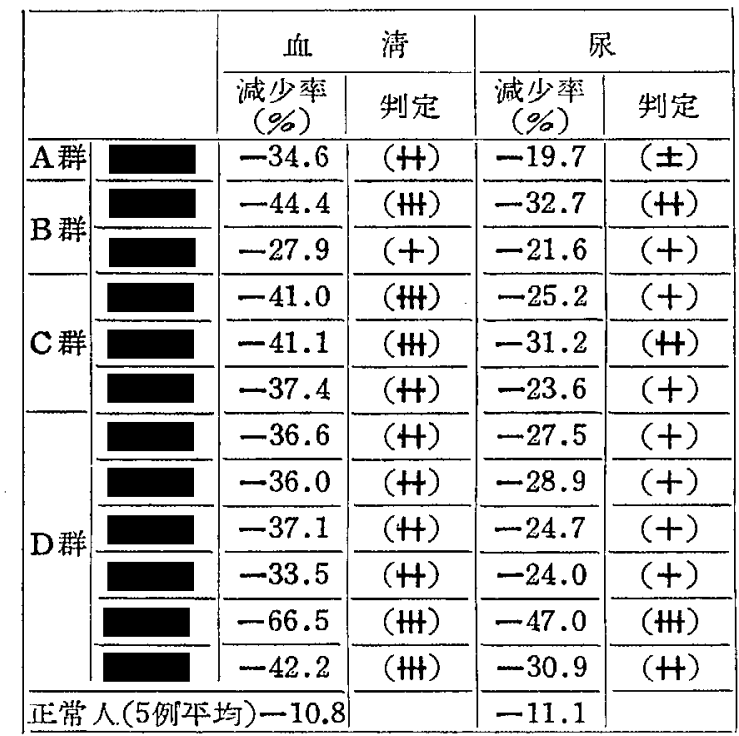

\section{III 治療成綪き中心として觀た考察}

1）入院前の治療：入院前の治療の有然につい ては前述の通りであるが，その治療の内譯を見る とA，B兩群では鉄劑，ビタミン $\mathrm{B}_{12}$, 盰葴の生食 等が極めて少數の例にみられ，又 $\mathrm{C} ， \mathrm{D}$ 兩群では

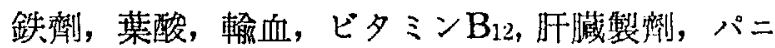
ールチン，メチオニン等が少數例に見られる。然 し，その詳細については充分明らかではない，但 し，少なくとも長期間に亘り，奆分なる治療を受 けたものは 1 例もなかつた。

2）入院後の治療：入院後行なつた治療の内， 特に有効と思われたものについて述へる。 i ） $\mathrm{A}$ 群( 3 例)：全例に反復輸血を行なつたが ，何れも有効であつた. 輸血は1回量50〜 100ccを 2 乃至 3 日每に 3 力月乃至 1 年數力月に亘り, 總 量約 3〜11 $l$ に及んだ.その内の 2 例には骨髓内 輸血( 1 回量50ccを 1 週 2 乃至 3 回)を行なつた。 葉酸は 1 回量 5 〜 210mgを毎日皮下或は静脈内に $1 \sim 15$ 力月間に亘り, 紸量 $0.33 \sim 11.5 \mathrm{~g}$ を用い, 3例共に有効であつた。其他鉄劑，牛の䀒贜或は

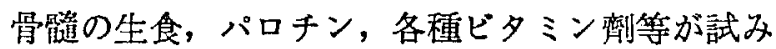
られたが，何れも效果不確實であつた。殊に上記 3 例中 2 例( 有効で，又他の1例(口はサルバルサン注射に 基つく例であるが，輸血のみにより著明な血液像 の好轉をみたが, 又葉酸の併用も，有效であつた。

ii） B群 ( 3 例): 3 例共に反復輸血加有勃で あつた。輸血は1四量 50〜 200cc を1〜3日毎 （輕快後は 7 日毎)に約 $1 \sim 2$ 年閒に亘り, 總量約 $2.8 \sim 8.8 l$ を静注した, 葉酸, ビタミン $\mathrm{B}_{12}$, メチオニン各 1 例に有効であつた。葉酸は毎日 15 $\sim 300$ mg宛，䄪 1 年 9 力月間に總量 $18.3 \mathrm{~g}$ を投與

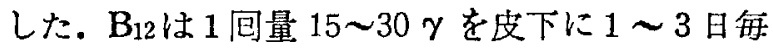
に 2 年 9 カ月間 (總計 $7.6 \mathrm{mg}$ ) 投與した.メチオ ニン゙は1国量 100〜 140mgを皮下に毎日，約 1 年 3 力月間（總量 $25.78 \mathrm{~g}$ ) 用いた。その他, 各種 ビタミン，パロチン，コーチソンン，铁劑，榜酸製 捯，䀒臓製劑等も用いられたが效果は不碓實であ つた，向，前記 3 例中の第 1 例(口)では, 輸血 と $\mathrm{B}_{12}$ 及びメテオニンの併用により或程度貧血が 回復したが，その後輸血を中止したにも拘らず， 貧血は更に回復の傾向を示した．第 2 例 はサルバルサン注射による例であるが，輸血に骨 縋のX線刺激照射を侀用して，輕快した．第 3 例 （正）は最初輸血のみにより可成り急速に貧血 の回復を見たが，コーチゾン使用後筫血が惡化し た。其處で輸血に葉酸を例用して漸次貧血の回復 を見た。

iii） $\mathrm{C}$ 群(10例)：区復輸血を行なつた 8 例中 5 例に於いて一過性の效果を認めた。輸血は 1 回量 $50 \sim 100 \mathrm{cc}$ を $1 \sim 7$ 日每に 1 力月〜 1 力年に亘り 
總量 $2 \sim 14 l$ を投其した。葉酸は 6 例中 4 例に一 過性の刘果思た。葉酸は 1 包量 $30 ， 100 ， 200$ ， 400mg夗 1 2 日每に20日〜15力月間に亘り, 總

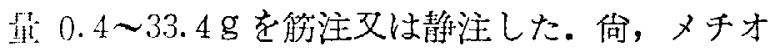
ンンは 2 例中 1 例に，又鉄剆は 8 例中 1 例に稍て 有效と琶われた。其他各種ビタミン放， A C T

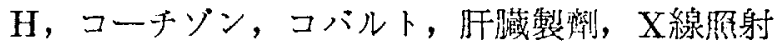
療法等を行なつたが，效果は不明であつた。向， これ等有效治療例の併用狀沉をみるに，輸血單獨 加 1 例, 輸血之葉酸併用が 4 例, 輸血とメチオ二 ン併用が 1 例である。

iv) $\mathrm{D}$ 群 (13例)：D群の内, 殊に入院後 1 力 月以内に死亡した 9 例に於いては全く治療效果が 見られなかつた。一過性ではあるが治療效果を認 め得たものでは反復輸血が 13 例中 4 例, 葉酸が 6 例中 1 例， $\mathrm{B}_{12}$ が 3 例中 1 例，メチオニンが 4 例 中1例で，而もそれ等の何れに於いても赤血球數 艾び血色装量の増加を認めたに過ぎない。份，D
群の内, 入院後比較的長期の經過を取つた 4 例で はA或はB群と略々同樣の治療法が行われた。 以 上述へた入院後の治療法の主なるものを一括表示 すると第13表の通りである。

3）退院後の狀況及び死因 :

i ） A 群：口例は大院中に結榜性助膜炎を併 發し，ストレプトマイシン療法，その他により血 液像が略て正常に回復した興味ある例であるが， 退院後約 1.5 年にして昮結核を發病して死亡し た. 又回例は退院時に肺結榜を發見され，退院 後特別の貧血治療を受けずに勤務していたが，退 院後䄪 5 年半を經て肺結榜の診姀のもとに當内科 に再入院した例である．入院の際の血液像及び骨 髓像は㱠ど全く正常であつた。

ii）B群：士例は輕快退院したが，其後貧血 治療を受けることなく，1年徣の現在何元氣に生 活している。回例は同しく輕快退院した例であ るが，退院後軷血々葉酸の併用を續けており， 2

第13表 入院後の主なる治療法

\begin{tabular}{|c|c|c|c|c|c|c|}
\hline & & $\begin{array}{c}\text { A }(3)^{\text {群 }} \\
\end{array}$ & $\begin{array}{c}\text { B }(3)^{\text {群 }} \\
\end{array}$ & $\begin{array}{l}\text { C 群 } \\
(10)\end{array}$ & $\begin{array}{l}\text { D 群 } \\
\text { (13) }\end{array}$ & $\begin{array}{c}\text { 詁 } \\
(29)\end{array}$ \\
\hline 翰 & 血. & $3(3)$ & $3(3)$ & $5(8)$ & $4(13)$ & $15(27)$ \\
\hline \multirow{2}{*}{$\begin{array}{l}\text { ビタ ミ } \\
\text { ン劑 }\end{array}$} & 望 & $3(3)$ & $1(2)$ & $4(6)$ & $1(6)$ & $9(17)$ \\
\hline & $\mathrm{B}_{12}$ & $0(1)$ & $1(2)$ & $0(5)$ & $1(3)$ & $2(11)$ \\
\hline \multirow{2}{*}{$\begin{array}{l}\text { ホルモ| } \\
\text { ン溂 }\end{array}$} & yーチ & & $0(1)$ & $1(3)$ & & $1(4)$ \\
\hline & $\mathrm{ACTH}$ & & & $0(1)$ & & $0(1)$ \\
\hline$x$ & f $\quad$ = & & $1(2)$ & $1(2)$ & $1(4)$ & $3(8)$ \\
\hline 鐵 & 製 & $0(3)$ & $0(2)$ & $0(8)$ & $0(4)$ & (17) \\
\hline 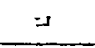 & バ ル & & & $0(1)$ & & $0(1)$ \\
\hline \multirow{2}{*}{$\begin{array}{l}\text { 胿臟 } \\
\text { 潦法 } \\
\end{array}$} & 肝 生 食 療 法 & $0(2)$ & & & & $0(2)$ \\
\hline & 肝 蔵 製 菲 & & $0(1)$ & $0(2)^{\circ}$ & $0(2)$ & $0(5)$ \\
\hline 骨 & 随 生 食 湆 法 & $0(1)$ & & & & $0(1)$ \\
\hline $\mathrm{X}$ & 線 療 法 & $0(1)$ & $0(1)$ & $0(1)$ & & $0(3)$ \\
\hline 核 & 酸 恝裴 & & $0(1)$ & & & $0(1)$ \\
\hline \multirow{5}{*}{$\begin{array}{l}\text { 抗 } \\
\text { 生 } \\
\text { 物 } \\
\text { 梊 }\end{array}$} & re $=シ \quad y \quad \nu$ & $0(2)$ & & & $0(5)$ & $0(7)$ \\
\hline & ストレプトマイシン & $1(1)$ & & & $0(3)$ & $1(4)$ \\
\hline & クロロマイセチン & & & & $0(2)$ & $0(2)$ \\
\hline & $\bar{T} \nabla 1 \otimes \geq$ & & & & $0(2)$ & $0(2)$ \\
\hline & $t-2 x \rightarrow 1 ; 2$ & & & & $0(2)$ & $0(2)$ \\
\hline
\end{tabular}

（）㭁は治療した患者の總数

（）外の教字は治祭效果を認めた患者の數

0 と記载したものは治療効果がないもの或は不磪葢なもの 
年後の現在なお，血液像の惡化を見ることなく韧 務けである。

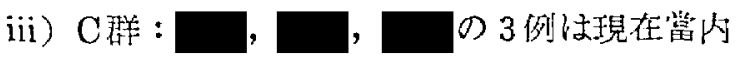
科で，又， の 2 例は他の病院で夫々入配 加穔山である. 回例は退院後死亡した。

iv） D群：死後の剖檢により死因の明ら斿な

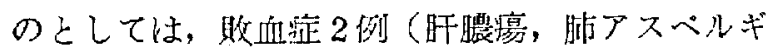
一ルス症各 1 例), 出血死 2 例 (膎出血, 性器出血 の备 1 例)である，份，其の他高度の貧血による 全身性衰弱が死因之考えられた例もある。

\section{IV 總括並びに考按}

著者等は土に入院した再不貧患者29例につ いて, 治療效果の存您に基づき, $\mathrm{A}, \mathrm{B}, \mathrm{C}, \mathrm{D}$ 群の 4 群に分办ち，主として㴗後並びに治療效果の面 から考察を行なつた. 先す年令について見ると、A 及びB群では青, 娤年者が多く、之に反しD群では 若年者及び高令老が多い。このことは惦症の豫後 判定の上に蛉考になるものと考えられる，從來サ ルバルサンにより惹起されたと思われる本症の報 告は多數あるが，その内沿潦により輕快した例が 少なくない，我々が經睃したサルバルサン中赫に よる2例も同じく良好なる經過を迻つた。文本湴 の經過中に肺結核を合併した 4 例中 2 例

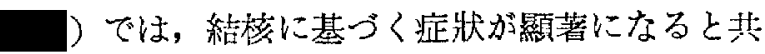
に血液像が著しく好瞦し，殆ど正常近く迄回復し たことは甚だ興味が深い。本2例の成因として骨 䦩の結核アレルギー扔至結核症が考えられた。

治療日數はA更び日群に於いては6力月乃至 3 年の長きに亘るものが多いが，このことは本症の 治療が相當期間に亘り，想耐強く續行される必要 があることを示陵している。入院前に治療を受け たものは，A及び B群ではC，D两群に比し可成り 多數に見られた。このことは本症の早期治療が旰 要であることを思わしめる。入院時の㫌状の内， 特に出血性素筫に基づく䆙吵の高度のものは， D兩群に多くみられた。特に，D群に於いてはそ の經過中は下血, 性器出血, 大量の鼻血, 眼底出血 等が多く見られ，而もこれ等の出血の内，死因とな つたものが少なくない，從つて本症の沿療に際し
ては特に出血倾向に對する對策が極めて緊要と考 えられる。出血時間及び㠜固時間の延長，Rumpel-Leede 氏現象の影性或は毛細血管抵抗の減持 は何れも各群共に認められた。然しA，B兩群では 治療後出血時間が短縮する傾向を認めたが，之に 反しD群ではむしろ延長する傾向が認められた。 このことは本症の豫後制定の上に出血時間の消長 も文一つの管り所となら得るものと思われる。

血液像では赤血球數, 血色素量, 白血球嚾及ひ 栓球數の著明なる減少は各群共に諗められる、從 つてこれ等の所見は必主しも踭後判定の指標とは なり得ない，但し，赤血球數が50万以下に著減し た我アの 2 例は何れ多死亡した。好中球百分臬の 著明なる娍少, リンパ球百分率の著明なる增加, 好 酸球の著娍历至消失或は跢球百分率の減少は何れ も概してA，B兩群に極めて少なく， C，D兩群心

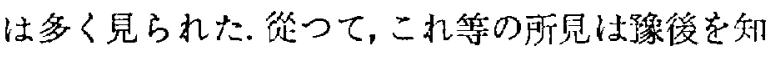
る上に大切な指票となる樣に考えられる，骨蹥有 核細胞數は前述の如く, 各群に於いて一定の美哭 が見られず，從つてこれは必ずしも本症の瑔後钊 走の基準とはなり蒦い樣である。骨䯕像に坽いて， 少なくとも赤来球及び好币球此率の著しい減少を 示す例に於いては。概して豫後不良のことが多い。

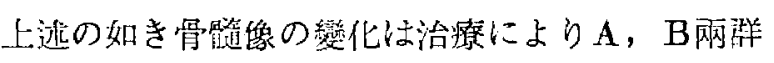
では濑次改善せられて正常に近づく倾何が見られ るが、之に反し C, D兩群(殊にD群)では治療にも

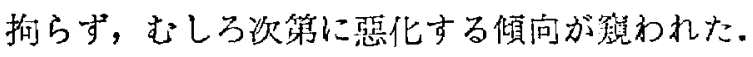

次に治療法の内では，㞋復輸血（骨慥内輸血をを 含む)加最も有效で，次いで某酸(特に大量投可!)， $\mathrm{B}_{12}$ ，メチオニン、铁浲等が有効と考光られたこれ

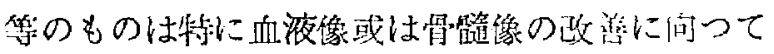
有效之考えられた。然しながら，これ等の療法はる れ罚獨で存効のものは少なく，有効例の殆ど總へ てはこれ等の併用療法によるものであり，殊に輸 血と葉酸(大量)の儌用が最も存刘と思われた。晾

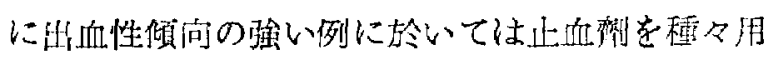
いて，出血による症斨の惡化，就中失血死を未然 に防ぐ可きである，又アレルギーにより菬起され たと考えられるものに對しては，コーチゾン，其 
の他の抗アレルギ一梁を用い，又感染症に對して は抗生物質，其の他を使用す可きである，向又榮 䈍についても注意を拂う必要がある。本症に剔脾 が偖效の場合があると言われているが，我々は剔 脾の經驗をもたなかつた。向, 我々は本症患者の 血清中に催貧血性物資の存在を確め，これを除去 乃至中和する方法を目下研究中であるが, 將來こ の方面よりする治潦法も極めて重要と信ずるもの である。

\section{$\mathbf{V}$ 結 論}

我々は當内科に入院した再不貧患者29例につい て，豫後並びに治療効果を中心として種々考察を 行なつた。皇の結果，患者の豫後判定の上に特に年 令, 血液像並びに骨䯕像（特に經過を追つての） 及び出血性素質（特に高度の）が良き指標となり 得ることを知り得た。治療法には種々あるが，現 在のところ的確なものが每く, 從つて本症の早期 診斷並びに早期治療が最も大切である. 我々の行 なつた治療法の内では, 反復輸血に葉酸の大量を 併用するのが最も有効と考えられた，向，我々は
本疾患の治療に際して，單に血液像を改善するの みでなく，出血性素質に對する治療法を講ずるこ とも等しく必要であることを知つた。

\section{主要㐱考文献}

1）藤野：日血䓌， $6 ， 121$, 昭 $17,-2)$ 大塚： 日血誌, 14,87 , 昭 $26 .-3)$ 小宮: 綜合醫學, $11,1$, 昭 $29 .-4)$ 河北：第14回日本醫學會總會 特別講演集，57-87，昭 $30 .-5$ ) 森田：血液學討 議會報告, 7,224 , 昭 $29 .-6$ ) 服部: 血液學討 議會報告， 7, 260, 昭 $29 .-7$ ) Heilmeyer, L. u. Begemann, H.: Handbuch der inneren Medizin, Bd. II : Blut und Blutkrankheiten 1951. -8) Rohr, K.: Das menschliche Knochenmark 1949. - 9) Wintrobe, M.: Clinical hematology 1949. - -10）天野：血液毦討議侖報告, 7，332，昭 29. 一 -11）三宅：再生不良性筫血治 療研究理報告, 昭 30. - 12) Watanabe, S.: Hiroshima J. Med. Sci. 3, 159, 1954. -13) 平福：血液祭討議會報告, 7,312 , 昭 $29 .-14$ ) 長谷川：血液學討議會報告， 7,248 , 昭 29 。 15）菊池，他：日队誌， $42 ， 413$ ，昭 $26 .-16$ ) 說田, 他: 第14国日血會, 昭 $27 .-17)$ 說田,

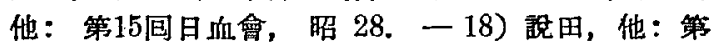
16回日血會, 昭 29. - -19) 說田, 他：第17间日 血會, 昭 30 .
[受稿・昭和30年12月19日] 